\title{
GROWTH AND YIELD OF CORN AND LEGUMES AS INFLUENCED BY N-LEVELS AND ROW INTERCROPPING SCHEMES $\mathbb{1}$
}

\author{
Santos B. Villocino, Jr. \\ Tiburcio Tancinco Memorial Institute of Science \\ and Technology, Calbayog City \\ and \\ Pedro P. Pascual \\ Department of Agronomy and Soil Science \\ College of Agriculture, Leyte State University \\ Visca, Baybay, Leyte
}

\section{ABSTRACT}

$N$ application and legume intercropping combinations gave better growth and yield performance of corn, peanut and mungbean. Application of $90 \mathrm{~kg} \mathrm{~N} / \mathrm{ha}$ gave the highest grain yield of corn while $\mathrm{N}$ application reduced the herbage and grain yields of peanut mixture; however, it increased herbage yield of mungbean but reduced grain yield. Corn + peanut intercropping combination gave higher gross margin than corn + mungbean combination. Single-row intercropping scheme gave lesser production cost than double-row that resulted to higher gross margin of either intercropping combination.

KEY WORDS: Intercropping combination. Row intercropping schemes. Component crops. Growth and yield. Corn. Legumes.

' Part of the M.S. thesis of the senior author' 


\section{INTRODUCTION}

At present, prices of most farm inputs, including fertilizer keep on increasing adversely affecting small-farm holders. With this condition, growing of leguminous crops is imperative to replenish nitrogen losses in the soil to reduce the demand for an expensive nitrogen fertilizer. These crops can fix atmospheric nitrogen $(N)$ in symbiosis with the root nodule bacteria (Rhizobium $\mathrm{sp}$.).

Corn (Zea mays L.) is an important food source and it is grown all over the country. However, despite favorable ${ }_{c}$ climatic conditions for growing, corn yield continues to decline each year. Although corn gets $\mathrm{N}$ from symbiotic $\mathrm{N}$-fixation with legumes, there is a need to add commercial $\mathrm{N}$ fertilizer for early growth and development and to enable the crop to attain optimum yield per unit area. This paper presents the effectiveness of peanut and mungbean in contributing better growth and yield of corn and legume in an intercropping scheme. In corn+legume row intercropping scheme, the effectiveness of peanut and mungbean in contributing better growth and yield of the crops is presented in this paper.

\section{METHODOLOGY}

A randomized complete block design (RCBD) was used with the following treatments: $T_{1}=$ corn intercropped with single row peanut applied with $0-60-60 \mathrm{~kg} \mathrm{~N}, \mathrm{P}_{2} \mathrm{O}_{5}, \mathrm{~K}_{2} \mathrm{O} / \mathrm{ha}$; $\mathrm{T}_{2}=$ corn intercropped with double rows of peanut spaced at $25 \mathrm{~cm}$ apart with 0-60-60 kg N, $\mathrm{P}_{2} \mathrm{O}_{5}$, $\mathrm{K}_{2} \mathrm{O} / \mathrm{ha} ; \mathrm{T}_{3}=$ corn intercropped with single row mungbean applied with 0-60-60 kg N, $\mathrm{P}_{2} \mathrm{O}_{5}, \mathrm{~K}_{2} \mathrm{O} / \mathrm{ha} ; \mathrm{T}_{4}=$ corn intercropped with double rows of mungbean spaced $25 \mathrm{~cm}$ apart applied with $0-60-60 \mathrm{~kg} \mathrm{~N}, \mathrm{P}_{2} \mathrm{O}_{5}$, $\mathrm{K}_{2} \mathrm{O} / \mathrm{ha} ; \mathrm{T}_{5}=\mathrm{corn}$ intercropped with single row peanut applied with 45$60-60 \mathrm{~kg} \mathrm{~N}, \mathrm{P}_{2} \mathrm{O}_{5}, \mathrm{~K}_{2} \mathrm{O} / \mathrm{ha} ; \mathrm{T}_{6}=$ corn intercropped with double rows of 
peanut spaced $25 \mathrm{~cm}$ apart applied with $45-60-60 \mathrm{~kg} \mathrm{~N}, \mathrm{P}_{2} \mathrm{O}_{5}, \mathrm{~K} 2 \mathrm{O} / \mathrm{ha}$; $\mathrm{T}_{7}=$ corn intercropped with single row of mungbean applied with 45-60$60 \mathrm{~kg} \mathrm{~N}, \mathrm{P}_{2} \mathrm{O}_{5}, \mathrm{~K} \mathrm{~K}_{2} \mathrm{O} / \mathrm{ha} ; \mathrm{T}_{8}=$ corn intercropped with double rows of mungbean spaced $25 \mathrm{~cm}$ apart applied with $45-60-60 \mathrm{~kg} \mathrm{~N}, \mathrm{P}_{2} \mathrm{O}_{5}$, $\mathrm{K}_{2} \mathrm{O} / \mathrm{ha} ; \mathrm{T}_{9}=\mathrm{corn}$ intercropped with single row peanut applied with 90 $60-60 \mathrm{~kg} \mathrm{~N}, \mathrm{P}_{2} \mathrm{O}_{5}, \mathrm{~K} 2 \mathrm{O} / \mathrm{ha} ; \mathrm{T}_{10}=$ corn intercropped with double rows of peanut spaced $25 \mathrm{~cm}$ apart applied with $90-60-60 \mathrm{~kg} \mathrm{~N}, \mathrm{P}_{2} \mathrm{O}_{5}, \mathrm{~K}_{2} \mathrm{O} / \mathrm{ha}$; $T_{11}=$ corn intercropped with single row mungbean applied with 90-60$60 \mathrm{~kg} \mathrm{~N}, \mathrm{P}_{2} \mathrm{O}_{5}, \mathrm{~K}_{2} \mathrm{O} / \mathrm{ha} ; \mathrm{T}_{12}=$ com intercropped with double rows of mungbean spaced $25 \mathrm{~cm}$ apart applied with $90-60-60 \mathrm{~kg} \mathrm{~N}, \mathrm{P}_{2} \mathrm{O}_{5}$, $\mathrm{K}_{2} \mathrm{O} / \mathrm{ha} ; \mathrm{T}_{13}=$ monocern applied with 60-30-30 kg N, $\mathrm{P}_{2} \mathrm{O}_{5}, \mathrm{~K}_{2} \mathrm{O} / \mathrm{ha} ; \mathrm{T}_{14}$ $=$ monopeanut applied with 30-30-30 kg N, $\mathrm{P}_{2} \mathrm{O}_{5}, \mathrm{~K}_{2} \mathrm{O} / \mathrm{ha} ; \mathrm{T}_{15}=$ monomungbean applied with $30-30-30 \mathrm{~kg} \mathrm{~N}, \mathrm{P}_{2} \mathrm{O}_{5}, \mathrm{~K}_{2} \mathrm{O} /$ ha.

Planting of corn was done at a distance of $100 \mathrm{~cm}$ between rows and $25 \mathrm{~cm}$ between hills; for the legume intercrops, planting was done at a distance of $50 \mathrm{~cm}$ between rows of corn for single row intercropping scheme and $37.5 \mathrm{~cm}$ for double-row intercropping scheme spaced at $25 \mathrm{~cm}$ apart.

The fertilizer materials used to satisfy the rates of application were urea (45-0-0), complete (14-14-14), solophos (0-20-0) and muriate of potash (0-0-60). Application of the levels of $N$ was split in two, at planting and one month after seedling emergence; $\mathrm{P}$ and $\mathrm{K}$ were applied at planting.

\section{RESULTS AND DISCUSSION}

\section{Agronomic Characteristics of Corn}

Regardiess of the legume intercrop and row intercropping scheme used, corn plants with no $\mathrm{N}$ fertilization tasseled and matured 42 
later (Table 1). Application of 90 and $45 \mathrm{~kg} \mathrm{~N} / \mathrm{ha}$ regardless of the legume intercrop and row intercropping scheme enhanced tasseling and maturity of corn. However, tasseling and maturity of corn applied with $45 \mathrm{~kg} \mathrm{~N} / \mathrm{h}$ a were delayed for one to two days. These results could be attributed to the effect of higher amount of nitrogen in promoting better growth and development of the plants that made them complete their life cycle earlier.

Corn intercropped with single row mungbean applied with $90 \mathrm{~kg}$ N/ha produced tassel and matured earlier, as early as corn alone, than corn plants with double row peanut applied with $45 \mathrm{~kg} \mathrm{~N} / \mathrm{ha}$. 'This plant reaction was probably due to less interplant competition for moisture, nutrients and space when planted alone or when it was intercropped with single low legume. The single row mungbean intercrop was farther from the rows of corn than the double row peanut; thus this did not show serious competition with corn for the necessary factors that affect the growth and development of a plant. This explains why corn intercropped with single row mungbean produced tassel and matured earlier, as early as corn alone, than corn intercropped with double row peanut at $45 \mathrm{~kg} \mathrm{~N} / \mathrm{ha}$. Herrera et al. (1976) claimed that interplant and inplant competitions for nutrients, water and light may seriously occur in an intercropping system.

Regardless of the row intercropping scheme and legume intercrop used, corn plants applied with $\mathrm{N}$ fertilizer had significantly higher stover yield than those that were not fertilized with nitrogen. These results support the findings of Catingan (1982) that application of $\mathrm{N}$ fertilizer as the rate appropriate for the crops stimulate roots, stem and leaf growth making the plants to photosynthesize effectively. 
Table 1. Agronomic characteristics of corn as influenced by N-levels and row intercropping scheme under corn+peanut and corn+mungbean combinations.

\begin{tabular}{|c|c|c|c|c|c|c|}
\hline \multirow[b]{2}{*}{ Treatments } & \multicolumn{3}{|c|}{$\mathrm{Na}$. of days from planting to } & \multirow{2}{*}{$\begin{array}{l}\text { Plant } \\
\text { Height } \\
\text { (cm) }\end{array}$} & \multirow{2}{*}{$\begin{array}{l}\text { Leaf } \\
\text { Area } \\
\text { Index } \\
\text { (LAI) }\end{array}$} & \multirow{2}{*}{$\begin{array}{l}\text { Stover } \\
\text { Yield } \\
\left(\mathrm{t} \mathrm{ha} \mathrm{a}^{-1}\right)\end{array}$} \\
\hline & emergence & tasseling & maturity & & & \\
\hline $\begin{array}{c}\mathrm{T}_{\mathrm{t}}=\mathrm{CN} \backsim \mathrm{SGR} \mathrm{PN} \\
(0-60-60)\end{array}$ & 4.33 & $59.33 a$ & $99.67 a$ & $139.19 \mathrm{c}$ & $1.16 \mathrm{c}$ & $1.17 \mathrm{~b}$ \\
\hline $\begin{array}{c}\mathrm{T}_{2}=\mathrm{CN}+\mathrm{DBR} P \mathrm{~N} \\
(0-60-60)\end{array}$ & 4.33 & $59.00 \mathrm{a}$ & $99.33 a b$ & $147.74 \mathrm{C}$ & $1.39 \mathrm{c}$ & $1.31 \mathrm{~b}$ \\
\hline $\begin{array}{c}T_{3}=C N+S G R M B \\
(0-60-60)\end{array}$ & $4.67^{\circ}$ & $59.17 a$ & $99.33 a b$ & $146.91 \mathrm{C}$ & $1.40 \mathrm{c}$ & $1.44 \mathrm{~b}$ \\
\hline $\begin{array}{c}T_{4}=C N+D B R M B \\
(0-60-60)\end{array}$ & 4.67 & $59.22 a$ & $99.67 a$ & $143.93 \mathrm{c}$ & $1.38 \mathrm{c}$ & $1.39 b$ \\
\hline $\begin{array}{c}T_{5}=C N+S G R \text { PN } \\
(45-60-60)\end{array}$ & 4.67 & $53.67 \mathrm{~b}$ & $97.67 \mathrm{~cd}$ & $182.74 \mathrm{~b}$ & $2.50 \mathrm{ab}$ & $2.77 \mathrm{a}$ \\
\hline $\begin{array}{c}T_{5}=\text { CN+DBR PN } \\
(45-60-60)\end{array}$ & 4.33 & $53.33 \mathrm{bc}$ & $98.33 \mathrm{abc}$ & $195.25 \mathrm{ab}$ & $2.53 a$ & $3.16 a$ \\
\hline $\begin{array}{c}T_{7}=\mathrm{CN}+\mathrm{SGR} M \mathrm{MB} \\
(45-60-60)\end{array}$ & 4.00 & $53.67 \mathrm{~b}$ & 98.33abc & $179.23 \mathrm{~b}$ & $2.15 b$ & $2.63 a$ \\
\hline $\begin{array}{c}T_{8}=C N+D B R M B \\
(45-60-60)\end{array}$ & 4.33 & $53.00 \mathrm{bcd}$ & $98.00 \mathrm{bcd}$ & $199.75 a b$ & $2.56 \mathrm{a}$ & $2.87 \mathrm{a}$ \\
\hline $\begin{array}{l}T_{9}=C N+S G R P N \\
(90-60-60)\end{array}$ & 4.33 & $52.33 \mathrm{cde}$ & $97.67 \mathrm{~cd}$ & $194.34 \mathrm{ab}$ & $2.66 \mathrm{a}$ & $3.65 \mathrm{a}$ \\
\hline $\begin{array}{l}\mathrm{T}_{10}=\mathrm{CN}+\mathrm{CDR} \text { PN } \\
(90-60-60)\end{array}$ & 4.00 & $53.00 \mathrm{bcd}$ & $97.67 \mathrm{~cd}$ & $202.10 \mathrm{ab}$ & $2.80 \mathrm{a}$ & $3.79 \mathrm{a}$ \\
\hline $\begin{array}{c}T_{11}=C N+S G R M B \\
(90-60-60)\end{array}$ & 4.33 & $52.00 \mathrm{de}$ & $96.67 \mathrm{de}$ & $196.76 \mathrm{ab}$ & $2.75 a$ & $.3 .52 \mathrm{a}$ \\
\hline $\begin{array}{c}\mathrm{T}_{12}=\mathrm{CN}+\mathrm{DBR} M B \\
(90-60-60)\end{array}$ & 4.00 & $52.00 \mathrm{de}$ & $97.00 \mathrm{cde}$ & $212.98 \mathrm{a}$ & $2.61 \mathrm{a}$ & $3.39 a$ \\
\hline $\begin{array}{c}T_{13}=\text { CN ALONE } \\
(60-30-30)\end{array}$ & 4.00 & $51.33 \mathrm{e}$ & $96.00 \mathrm{e}$ & $203.07 \mathrm{ab}$ & $2.83 a$ & $3.89 \mathrm{a}$ \\
\hline Grand Mean & 4.31 & 54.70 & 98.10 & 180.00 & 2.21 & 2.70 \\
\hline CV $(\%)$ & 11.00 & 1.22 & 0.71 & 6.92 & 8.98 & 25.86 \\
\hline
\end{tabular}

Treatment means within the column with a common letter are not significantly different from each other at $5 \%$ probability level based on Duncan's Multiple Range Test (DMRT)

Legend: $\quad \mathrm{CN}=$ corn; $\mathrm{PN}=$ peanut; $\mathrm{MB}=$ mungbean; $\quad \mathrm{SGRIDBR}=$ single/double row 
Significant difference in plant height was observed in treatment 12 against treatment 5 and 7 . This result implied that double rows of mungbean intercrop would influence the height of the companion crop. Mungbean is a photosensitive crop that stretches its canopies as high as corn. The competition for light, was also very high between corn and mungbean intercrop because the height of mungbean was almost the same as corn and there were two rows of it situated closer to corn.

Statistical difference in the LAI of corn was also observed. Treatment 8 had higher LAl than treatment 7 and $45 \mathrm{~kg} \mathrm{~N} / \mathrm{ha}$ : This result could be due to the effect of the closer association between corn and double row mungbean intercrop. The $\mathrm{N}$ applied to mungbean was also utilized by corn, since the double rows of mungbean were situated near the effective root zone of corn, hence increased the LAl. Also, mungbean is a leguminous crop that could fix atmospheric $N$. This would be beneficial to corn grown in close association.

\section{Yield and Yield Components of Corn}

Number of ears per corn plant was markedly affected by application of N. Application of 90 and $45 \mathrm{~kg} \mathrm{~N} / \mathrm{ha}$ similarly increased number of ears per corn plant (Table 2). Corn with no $\mathrm{N}$ fertilization bore single ears per plant. No marked difference, however, on the number of ears per plant between treatments with no $\mathrm{N}$ fertilization and low (45 kg N.ha) $\mathrm{N}$ level. Legume intercrop and row intercropping scheme did show interference on this parameter. 
Number of kernels per ear varied among treatments. Mungbean intercrop, regardless of the row intercropping scheme, gave greater number of kernels per ear than peanut as intercrop at the same level of $\mathrm{N}$. This result implied that mungbean is more advantageous to use as intercrop for corn than peanut. Probably, peanut has a higher water requirement than mungbean that competes with corn on the available soil moisture, thus, reducing the production of kernels per ear. It was also observed that single row mungbean in all levels of $\mathrm{N}$ gave greater number of kernels per corn ear than double row mungbean intercrop. This result maybe due to the effect of the single row mungbean-intercrosping that allows corn exposure in all growth factors as light, moisture and nutrients than double row mungbean intercropping. Effect of peanut intercrop on the number of kernels per ear, on the other hand, was influenced by the row intercropping scheme and level of $\mathrm{N}$ application. Number of kernels per ear was observed to be higher in double row peanut intercropping than in single row peanut intercropping between treatments with zero $\mathrm{N}$ and $45 \mathrm{~kg} N / \mathrm{ha}$. Increased application of $\mathrm{N}$ to $90 \mathrm{~kg} \mathrm{~N} / \mathrm{ha}$ reduced the number of kernels per ear when intercropped with double row peanut. These results maybe due to the efficiency of peanut in fixing atmospheric $\mathrm{N}$ at zero and $45 \mathrm{~kg} \mathrm{~N} / \mathrm{ha}$. And, the closer the distance of peanut intercrop to corn, the greater amount of available atmospheric $\mathrm{N}$ for consumption the greater the number of kernels may be produced. On the other hand, the high amount $(90 \mathrm{~kg} \mathrm{~N} / \mathrm{ha}$ ) of $\mathrm{N}$ application reduced the efficiency of peanut in fixing atmospheric $\mathrm{N}$, thus, competing with corn on the available soil N. Greater nutrient competition has occurred in double row peanut intercropping than in single row intercropping and therefore number of kernel per ear was lower in the former than in the latter.

Generally, the number of kernels per ear increased as the level of $\mathrm{N}$ applied increased up to $90 \mathrm{~kg} \mathrm{~N} / \mathrm{ha}$. This result proved that $\mathrm{N}$ is an 46 
Table 2. Yield and yield components of corn a influenced by $\mathrm{N}$-levels and row intercropping schemes under com+peanut and corn+mungbean combinations.

\begin{tabular}{|c|c|c|c|c|c|}
\hline Treatments & $\begin{array}{l}\text { No. of } \\
\text { ears per } \\
\text { plant }\end{array}$ & $\begin{array}{l}\text { No. of } \\
\text { Kernels } \\
\text { Per ear. }\end{array}$ & $\begin{array}{c}\text { Weight of } \\
1,000 \\
\text { grains } \\
\text { (g) }\end{array}$ & $\begin{array}{l}\text { Grain } \\
\text { Yield } \\
\text { (t ha-1) }\end{array}$ & $\begin{array}{c}\text { Harvest } \\
\text { Index } \\
\text { (HI) }\end{array}$ \\
\hline $\begin{array}{c}T_{i}=C N+S G R P N \\
(0-60-60)\end{array}$ & $1.00 \mathrm{~b}$ & 32.071 & $175.00 \mathrm{c}$ & $0.163 \mathrm{e}$ & $0.123 d$ \\
\hline $\begin{array}{c}\mathrm{T}_{2}=\mathrm{CN}+\mathrm{DBR} \text { PN } \\
(0-60-60)\end{array}$ & $1.00 \mathrm{~b}$ & $34.80 \mathrm{k}$ & $178.67 \mathrm{c}$ & $0.159 \mathrm{e}$ & $0.115 d$ \\
\hline $\begin{array}{c}\mathrm{T}_{3}=\mathrm{CN}+\mathrm{SGR} M \mathrm{MB} \\
(0-60-60)\end{array}$ & $1.00 \mathrm{~b}$ & $83.17 i$ & $177.00 \mathrm{c}$ & $0.386 \mathrm{de}$ & $0.220 \mathrm{bc}$ \\
\hline $\begin{array}{c}T_{4}=\text { CN+DBR MB } \\
(0-60-60)\end{array}$ & $1.00 \mathrm{~b}$ & $45.73 \mathrm{j}$ & $190.33 \mathrm{bc}$ & $0.249 \mathrm{e}$ & $0.143 \mathrm{~cd}$ \\
\hline $\begin{array}{c}T_{5}=C N+S G R P N \\
(45-60-60)\end{array}$ & 1.10ab & $160.57 \mathrm{~h}$ & $212.00 \mathrm{ab}$ & $0.952 \mathrm{~cd}$ & $0.25 \mathrm{fabc}$ \\
\hline $\begin{array}{c}T_{6}=C N+D B R \text { PN } \\
(45-60-60)\end{array}$ & $1.03 \mathrm{ab}$ & $163.57 \mathrm{~g}$ & $215.00 \mathrm{ab}$ & $0.964 \mathrm{~cd}$ & $0.236 \mathrm{bc}$ \\
\hline $\begin{array}{c}\mathrm{T}_{7}=\mathrm{CN}+\mathrm{SGR} M \mathrm{MB} \\
(45-60-60),\end{array}$ & $1.07 \mathrm{ab}$ & $192.73 \mathrm{e}$ & $218.00 \mathrm{ab}$ & $1.031 \mathrm{bc}$ & 0.27 1abc \\
\hline $\begin{array}{c}T_{8}=C N+D B R M B \\
(45-60-60)\end{array}$ & $1.10 \mathrm{ab}$. & $175.10 \mathrm{f}$ & $217.33 \mathrm{ab}$ & $1.223 b c$ & $0.296 \mathrm{abc}$ \\
\hline $\begin{array}{c}T_{9}=\mathrm{CN}+\mathrm{SGR} P \mathrm{PN} \\
(90-60-60)\end{array}$ & $1.13 a$ & $206.97 \mathrm{c}$ & $222.67 \mathrm{a}$ & $1603 \mathrm{ab}$ & $0.309 \mathrm{abc}$ \\
\hline $\begin{array}{l}T_{10}=C N+C D R \text { PN } \\
(90-60-60)\end{array}$ & $1.13 a$ & $201.57 d$ & $217.33 \mathrm{ab}$ & $1.494 a b c$ & $0.283 \mathrm{abc}$ \\
\hline $\begin{array}{c}T_{11}=C N+S G R M B \\
(90-60-60)\end{array}$ & $1.13 a$ & $265.43 a$ & $239.33 a$ & $1.876 \mathrm{a}$ & $0.352 \mathrm{a}$ \\
\hline $\begin{array}{c}T_{12}=C N+D B R M B \\
(90-60-60)\end{array}$ & $1.13 \mathrm{a}$ & $232.20 \mathrm{~b}$ & $226.33 a$ & $1.640 \mathrm{ab}$ & $0.320 \mathrm{ab}$ \\
\hline $\begin{array}{c}T_{13}=\text { CN ALONE } \\
(60-30-30)\end{array}$ & $1.17 a$ & $237.23 \mathrm{~b}$ & $236.00 \mathrm{a}$ & $1.860 \mathrm{a}$ & $0.319 a b$ \\
\hline Grand Mean & 1.08 & 156.70 & 292.62 & 1.046 & $0.319 a b$ \\
\hline CV (\%) & 14.17 & 28.32 & 7.83 & 30.92 & 19.03 \\
\hline
\end{tabular}

Treatment means within the column with a common letter are not significantly different from each other at $5 \%$ probabilify level based on Duncan's Multiple Range Test (DMRT)

Legend:

$$
\mathrm{CN}=\text { corn; } \mathrm{PN}=\text { peanuk; } \mathrm{MB}=\text { mungbean; } \mathrm{SGR/DBR}=\text { single/double row }
$$


essential element necessary for the growth and development of the plants.

Nitrogen fertilization influenced the weight of corn grains. However, no significant difference was observed among treatments at low and high levels of $\mathrm{N}$ in the weight of 1,000 grains. On the otiner hand, corn grains obtained from treatments with zero $\mathrm{N}$ level weighed lighter than with $N$. This result was attributed to the fact that plants without $\mathrm{N}$ produced smaller grains and are therefore lighter.

Grain yield (t ha-1) of corn was greatly influenced by the application of $N$. It was observed that application of $90 \mathrm{~kg} \mathrm{~N} / \mathrm{ha}$ obtained higher yield that at low $\mathrm{N}$ level ( $45 \mathrm{~kg} \mathrm{~N} / \mathrm{ha}$ ) and with no $\mathrm{N}$. Regardless of the $\mathrm{N}$ level, legume intercrop and row intercropping scheme did not show significant effect on this parameter.

Highest index was obtained in treatment 1 and the lowest harvest index was obtained in treatment 2. High harvest index was attributed by the production of high economic yield. Obviously, application of $\mathrm{N}$ influenced the conversion of more photosynthates into grains as mahifested by the result obtained. In contrast, no $\mathrm{N}$ application gave low harvest index of corn.

\section{Agronomic Characteristics of Peanut}

Statistical differences were observed between monopeanut and peanut in mixture regardless of the row intercropping scheme and $N$ level on the number of days from planting to flowering and maturity (Table 3). Regardless of the row intercropping scheme and $\mathrm{N}$ level used, monoculture peanut flowered and matured the earliest. This result may be due to the exposure of peanut in pure stand with factors 
Table 3. Agronomic characteristics of peanut as influenced by $\mathrm{N}$-levels and row intercropping scheme under corn+peanut combination.

\begin{tabular}{|c|c|c|c|c|c|c|}
\hline \multirow{2}{*}{ Treatments } & \multicolumn{3}{|c|}{ No. of days from planting to: } & \multirow{2}{*}{$\begin{array}{c}\text { No. of } \\
\text { nodules } \\
\text { per } \\
\text { plant }\end{array}$} & \multirow{2}{*}{$\begin{array}{l}\text { Plant } \\
\text { height } \\
\text { (cm) }\end{array}$} & \multirow{2}{*}{$\begin{array}{l}\text { Herba } \\
\text { ge } \\
\text { Yield } \\
\left.\text { (t ha' }{ }^{\prime}\right)\end{array}$} \\
\hline & emergence & flowering & maturity & & & \\
\hline $\begin{array}{c}T_{1}=C N+S G R P N \\
(0-60-60)\end{array}$ & 5.33 & $30.67 a$ & 100.33ab & 133.33 & 59.23 & $3.13 \mathrm{c}$ \\
\hline $\begin{array}{c}T_{2}=\text { CN+DBR PN } \\
(0-60-60)\end{array}$ & 5.00 & $30.33 a$ & 100.67 & 156.33 & 61.87 & $4.80 \mathrm{~b}$ \\
\hline $\begin{array}{c}\mathrm{T}_{5}=\mathrm{CN}+\text { SGR PN } \\
(45-60-60)\end{array}$ & 5.00 & $31.00 \mathrm{a}$ & $100.00 \mathrm{ab}$ & 156.00 & 61.87 & $3.15 c$ \\
\hline $\begin{array}{c}T_{6}=C N+D B R P N \\
(45-60-60)\end{array}$ & 5.33 & $31.33 \mathrm{a}$ & $100.00 \mathrm{ab}$ & 158.00 & 60.47 & $3.31 \mathrm{c}$ \\
\hline $\begin{array}{c}T_{9}=C N+S G R P N \\
(90-60-60)\end{array}$ & 5.00 & $30.67 a$ & $99.33 \mathrm{bc}$ & 127.67 & 62.87 & $2.39 \mathrm{c}$ \\
\hline $\begin{array}{c}T_{10}=C N+D B R P N \\
(90-60-60)\end{array}$ & 5.33 & $31.67 a$ & $100.67 a$ & 140.67 & 58.23 & $3.29 \mathrm{c}$ \\
\hline $\begin{array}{c}T_{14}=\text { peanut alone } \\
(30-30-30)\end{array}$ & 5.00 & $28.67 \mathrm{~b}$ & $98.33 \mathrm{c}$ & 197.00 & 66.20 & $6.36 \mathrm{a}$ \\
\hline Grand Mean & 5.14 & 30.62 & 99.91 & $\{52.71$ & 61.74 & 3.78 \\
\hline C.V. $(\%)$ & 15.00 & 2.29 & 0.67 & 20.03 & 9.37 & 19.37 \\
\hline
\end{tabular}

Treatment means within the column with a common letter are not significantly different from each other at $5 \%$ probability level based on Duncan's Multiple Range Test (DMRT)

Legend: $\quad C N=$ corn; $P N=$ peanut; $S G R / D B R=$ single/double row

responsible for the enhancement of its flowering, light in particular. Light is essential to the growth and development of the plant that when absent, the plant remains in its vegetative growth, or if a portion of the light is intercepted by the above canopy of corn, this will delay the flowering and maturity of peanut. As observed, monopeanut matured earlier than peanut associated with corn. Also, a marked difference was observed on the maturity of peanut between treatment 9 and 
treatment 10 with the same level of $\mathrm{N}(90 \mathrm{~kg} \mathrm{~N} / \mathrm{ha})$. Both treatment experienced light competition with corn; however, treatment 10 has denser plant population than treatment 9 , thus, there was a greater light competition among peanuts in the former than in the latter treatment.

Application of $\mathrm{N}$ did not significantly influence the herbage yield of peanut. Monopeanut treatment obtained the highest herbage yield since this has greater plant population per unit area over peanut in mixture. On the other hand, treatment 2 obtained significantly higher herbage yield than the other treatment of peanut in mixture. This result implied that peanut is less responsive to nitrogen application. It is capable of fixing atmospheric $\mathrm{N}$ for nourishment, better growth and development.

\section{Yield and Yield Components of Peanut}

Application of $\mathrm{N}$ significantly reduced the grain yield of peanut when grown as intercrop with corn (Table 4). Regardless of the row intercropping scheme, the higher $\mathrm{N}$ applied, the lower the grain yield of peanut. This result maybe attributed to the effect of high $\mathrm{N}$ fertilization that favors its vegetative growth at the expense of grain production. Also, the shade of tall and broader leaves of corn at high $\hat{N}$ level contributed to this effect. Shading affects the photosynthetic activity of peanut, thus, affecting grain production. Better utilization of the environmental resources, light in particular, have been considered responsible for yield increase due to intercropping (Whyte et al., 1982).

\section{Agronomic Characteristics of Mungbean.}

There was no marked difference between treatments on the number of days from planting to flowering of mungbean in mixture 
Table 4. Yield and yield component of peanut as influenced by $\mathrm{N}$-level and row intercropping scheme under corn+peanut combination

\begin{tabular}{|c|c|c|c|c|c|}
\hline Treatments & $\begin{array}{c}\text { No. of } \\
\text { pods } \\
\text { per plant }\end{array}$ & $\begin{array}{l}\text { No. of } \\
\text { kernels } \\
\text { per pod }\end{array}$ & $\begin{array}{l}\text { Weight of } \\
1,000 \text { seeds } \\
\text { (g) }\end{array}$ & $\begin{array}{l}\text { Grain } \\
\text { Yield } \\
\text { (t ha. } 1 \text { ) }\end{array}$ & $\begin{array}{c}\text { Harvest } \\
\text { Index } \\
\text { (HI) }\end{array}$ \\
\hline $\begin{array}{l}T_{1}=C N+S G R P N \\
(0-60-60)\end{array}$ & 10.63 & 1.87 & 463.67 & $0.651 \mathrm{bc}$ & 0.228 \\
\hline $\begin{array}{l}T_{2}=C N+D B R P N \\
(0-60-60)\end{array}$ & 9.70 & 1.91 & 447.33 & $0.748 \mathrm{~b}$ & 0.195 \\
\hline $\begin{array}{c}T_{5}=C N+S G R P N \\
(45-60-60)\end{array}$ & 12.57 & 1.80 & 450.67 & $0.575 c$ & 0.205 \\
\hline $\begin{array}{l}T_{6}=C N+D B R P N \\
(45-60-60)\end{array}$ & 9.93 & 1.86 & 451.00 & $0.617 \mathrm{bc}$ & 0.211 \\
\hline $\begin{array}{l}T_{9}=C N+S G R P N \\
(90-60-60)\end{array}$ & 9.47 & 1.90 & 456.00 & $0.483 \mathrm{c}$ & 0.226 \\
\hline $\begin{array}{l}T_{10}=C N+C D R P N \\
(90-60-60)\end{array}$ & 7.30 & 1.81 & 471.00 & $0.509 \mathrm{c}$ & 0.184 \\
\hline $\begin{array}{l}\text { T14CN ALONE } \\
(60-30-30)\end{array}$ & 12.10 & 1.89 & 440.00 & $1.512 \mathrm{a}$ & 0.261 \\
\hline Grand Mean & 10.24 & 1.86 & 454.24 & 0.728 & 0.26 \\
\hline $\mathrm{CV}(\%)$ & 19.31 & 3.45 & 5.66 & 17.88 & 14.28 \\
\hline
\end{tabular}

Treatment means within the column with a common letter are not significantly different from - each other at $5 \%$ probability level based on Duncan's Multiple Range Test (DMRT)

Legend: $\quad \mathrm{CN}=$ corn; $\mathrm{PN}=$ peanut; $\mathrm{SGR} / \mathrm{DBR}=$ single/double row

(Table 5). However, monomungbean had flowered earlier than mungbean in mixture. This result could be attributed to the exposure of monomungbean to less competition on the growth factors, particularly light. Exposure of mungbean to poor light prolonged the vegetative growth of the plant.

Maturity of mungbean was also affected by the shade of corn in association. Mungbean intercropped with corn matured later than monomungbean. Further delay in maturity was observed to mungbean intrecrop with no $\mathrm{N}$ fertilization. This result-implied that mungbean needs starter amount of $\mathrm{N}$ and exposure to light for better growth and development. 
Table 5. Agronomic characteristics of mungbean as influenced by N-levels and row intercropping scheme under corn+mungbean combination.

\begin{tabular}{|c|c|c|c|c|c|c|}
\hline \multirow{2}{*}{ Treatments } & \multicolumn{3}{|c|}{ No. of days from planting to: } & \multirow{2}{*}{$\begin{array}{c}\text { No. of } \\
\text { nodules } \\
\text { per } \\
\text { plant }\end{array}$} & \multirow{2}{*}{$\begin{array}{l}\text { Plant } \\
\text { height } \\
(\mathrm{cm})\end{array}$} & \multirow{2}{*}{$\begin{array}{l}\text { Herba } \\
\text { ge } \\
\text { Yield } \\
(t \text { ha'l) }\end{array}$} \\
\hline & $\begin{array}{l}\text { emerge } \\
\text { nce }\end{array}$ & flowering & maturity & & & \\
\hline $\begin{array}{c}T_{3}=C N+\text { SGR PN } \\
(0-60-60)\end{array}$ & 3.67 & $39.33 a$ & $68.67 a$ & 54.00 & $61.64 \mathrm{c}$ & $1.05 f$ \\
\hline $\begin{array}{c}T_{4}=C N+\text { CBRPN } \\
(0-60-60)\end{array}$ & 4.00 & $39.67 a$ & $68.33 a$ & 59.67 & $64.90 \mathrm{c}$ & $1.19 !$ \\
\hline $\begin{array}{c}T_{7}=C N+S G R P N \\
(45-60-60)\end{array}$ & 3.67 & $39.33 a$ & $64.00 \mathrm{~b}$ & 69.00 & $78.40 \mathrm{~b}$ & $1.44 \mathrm{e}$ \\
\hline $\begin{array}{c}T_{8}=C N+D B R P N \\
(45-60-60)\end{array}$ & $3.33^{\circ}$ & $39.33 \mathrm{a}$ & $64.33 \mathrm{~b}$ & 46.67 & $83.72 \mathrm{ab}$ & $1.64 \mathrm{~d}$ \\
\hline $\begin{array}{c}T_{11}=C N+S G R P N \\
(90-60-60)\end{array}$ & 3.67 & $39.33 a$ & $63.33 \mathrm{~b}$ & 51.00 & $81.30 b$ & $2.06 \mathrm{c}$ \\
\hline $\begin{array}{c}T_{12}=C N+D B R P N \\
(90-60-60)\end{array}$ & 3.67 & $39.67 a$ & $63.67 \mathrm{~b}$ & 27.00 & $95.80 \mathrm{a}$ & $2.35 b$ \\
\hline $\begin{array}{l}T_{15}=\text { mungbean } \\
\quad \text { alone }(30-30-30)\end{array}$ & 3.33 & $38.33 b$ & $61.63 \mathrm{c}$ & 41.67 & $77.50 \mathrm{~b}$ & $3.19 \mathrm{a}$ \\
\hline Grand Mean & 3.62 & 39.29 & 64.81 & 49.86 & 77.61 & 1.85 \\
\hline C.V. $(\%)$ & 15.17 & 1.06 & 1.21 & 41.65 & 8.71 & 5.26 \\
\hline
\end{tabular}

Treatment means. within the column with a common letter are not significantly different from each other at $5 \%$ probabilify level based on Duncan's Multiple Range Test (DMRT)

Legend: $\quad C N=$ corn ; $M B=$ mungbean; $S G R / D B R=$ single/double row

Generally, application of $\mathrm{N}$ influenced the height of mungbean. It was observed that mungbeans with $\mathrm{N}$ were taller than with no $\mathrm{N}$. This finding proved that $N$ is essential in promoting better growth and development of the plant. In comparison to treatments with $\mathrm{N}$, treatment 12 had the tallest mungbeans. This result could be attributed to the photosensitivity of the mungbean plants since in this treatment, corn canopy cover was heavy that hindered light from reaching the mungbean canopy. 
Planting density greatly influenced the herbage yield of mungbean. Planting of mungbean alone obtained the highest herbage yield per hectare since this has greater plant population per unit area. Double row mungbean intercrop gave higher herbage yield than single row mungbean intercrop at the same level of $\mathrm{N}$ also because of having greater plant population per unit area. Nitrogen application also influenced the herbage yield of mungbean per hectare. The higher $N$ was applied the heavier herbage yield. Nitrogen promoted the vegetative growth and development of the plant as manifested by the increase in plant height, bigger stems and heavy foliage.

\section{Yield and Yield Components of Mungbean}

Monomungbean obtained the highest grain yield which was statistically different from the grain yields of mungbean in mixture (Table 6). This result was due to the greater plant population of monoculture mungbean per unit area. Treatment 4 produced significantly higher grain yield than treatments 8,11 and 12 . This result maybe attributed to the exposure of mungbean plant to greater light intensity. Corn under this treatment was short and had lesser foliage that allowed greater light penetration that enhanced the photosynthetic activity of the plants, hence, increased grain production. Application of $\mathrm{N}$, regardless of the amount applied and row intercropping used, did not influenced the grain yield of mungbean. Furthermore, no significant grain difference was observed between treatments of mungbean in mixture with no $\mathrm{N}$ fertilization

Treatment 4 obtained the highest harvest index compared to the other treatments. This means that mungbean plants had higher economic yield than biological yield compared to the other treatments. Mungbean under this treatment was more exposed to sun, thus greater amount of photosynthates were produced and converted into grains. 
Table 6. Yield and yield component of mungbean as influenced by $N$-level and row intercropping scheme under corn+mungbean combination.

\begin{tabular}{|c|c|c|c|c|c|}
\hline Treatments & $\begin{array}{l}\text { Ave. no } \\
\text { of pods } \\
\text { per } \\
\text { plant }\end{array}$ & $\begin{array}{l}\text { No. of } \\
\text { seeds } \\
\text { per pod }\end{array}$ & $\begin{array}{c}\text { Weight } \\
\text { of } 1,000 \\
\text { seeds } \\
\text { (g) }\end{array}$ & $\begin{array}{c}\text { Grain } \\
\text { Yield } \\
\text { (t ha-1) }\end{array}$ & $\begin{array}{l}\text { Harvest } \\
\text { Index } \\
\text { (HI) }\end{array}$ \\
\hline $\begin{array}{c}T_{3}=C N+S G R M B \\
(0-60-60)\end{array}$ & 8.93 & 8.15 & 57.33 & $0.192 \mathrm{~cd}$ & $0.90 \mathrm{bc}$ \\
\hline $\begin{array}{c}T_{4}=C N+D B R M B \\
(0-60-60)\end{array}$ & 4.93 & 8.04 & 53.00 & $0.315 b$ & $0.274 a$ \\
\hline $\begin{array}{c}\mathrm{T}_{7}=\mathrm{CN}+\mathrm{SGR} M \mathrm{MB} \\
(45-60-60)\end{array}$ & 9.23 & 8.30 & 54.67 & $0.245 b c$ & $0.195 b$ \\
\hline $\begin{array}{c}\mathrm{T}_{8}=\mathrm{CN}+\mathrm{DBR} \mathrm{MB} \\
(45-60-60)\end{array}$ & 6.90 & 7.69 & 48.67 & $0.182 \mathrm{~cd}$ & $0.135 c d$ \\
\hline $\begin{array}{c}T_{11}=C N+S G R M B \\
(90-60-60)\end{array}$ & 6.97 & 8.34 & 51.33 & $0.151 d$ & $0.094 d$ \\
\hline $\begin{array}{c}\mathrm{T}_{12}=\mathrm{CN}+\mathrm{OBR} \mathrm{MB} \\
(90-60-60)\end{array}$ & 4.93 & 8.67 & 53.33 & $0.222 \mathrm{~cd}$ & $0.119 d$ \\
\hline $\begin{aligned} T_{15}= & \text { mungbean } \\
& \text { alone }(30-30-30)\end{aligned}$ & 7.90 & 8.52 & 53.67 & $0.550 \mathrm{a}$ & $0.198 \mathrm{~b}$ \\
\hline Grand Mean & 7.12 & 8.24 & 53.14 & 0.266 & 0.179 \\
\hline $\mathrm{CV}(\%)$ & 28.14 & 9.43 & 6.67 & 17.51 & 22.22 \\
\hline
\end{tabular}

Treatment means within the column with a common lefter are not significantly different from each other at 5\% probability level based on Duncan's Multiple Range Test (DMRT)

Legend: $\quad C N=$ corn; $M B=$ mungbean; $S G R / D B R=$ single/double row

Treatments applied with $\mathrm{N}$ obtained lower harvest index since mungbean under these treatments were exposed to greater competition on all growth factors with corn, especially sunlight which is the plant's source of energy.

\section{Land Equivalent Ratio (LER)}

Application of $90 \mathrm{~kg} \mathrm{~N} / \mathrm{ha}$, regardless of the legume intercrop and row intercropping scheme showed significant advantage of 
intercropping over monocropping in terms of productivity per unit land area (Table 7). LER values under these treatments exceeded value of 1.0 of which the excess numerical value was the value advantage of intercropping against monocropping. For instance, treatment 12 which obtained the highest LER value of 1.347 meant monocropping of corn or mungbean needed additional land area of $3,470 \mathrm{~m}^{2}$ to compensate the productivity of intercropping corn and mungbean per hectare.

Table 7. Land Equivalent Ratio (LER) of corntpeanut and corn+mungbean combinations as influenced by $\mathrm{N}$-levels and row intercropping schemes

\begin{tabular}{|c|c|}
\hline Treatments & LER \\
\hline$T 1=C N+$ SGR PN $(0-60-60)$ & $0.533 \mathrm{e}$ \\
\hline $\mathrm{T} 2=\mathrm{CN}+$ DBR PN $(0-60-60)$ & $0.637 \mathrm{e}$ \\
\hline$T 3=C N+S G R M B(0-60-60)$ & $0.580 \mathrm{e}$ \\
\hline$=C N+D B R M B(0-60-60)$ & $0.730 \mathrm{de}$ \\
\hline$=C N+S G R P N(45-60-60)$ & $1.000 \mathrm{~cd}$ \\
\hline$=C N+D B R P N(45-60-60)$ & $0.950 \mathrm{~cd}$ \\
\hline$T 7=C N+$ SGR MB $(45-60-60)$ & $1.000 \mathrm{~cd}$ \\
\hline $\mathrm{T} 8=\mathrm{CN}+\mathrm{DBR} M B(45-60-60)$ & $1.003 \mathrm{bcd}$ \\
\hline$T 9=C N+$ SGR PN $(90-60-60)$ & $1.2050 \mathrm{abc}$ \\
\hline$T 10=C N+$ DBR PN $(90-60-60)$ & $1.227 \mathrm{abc}$ \\
\hline$T 11=C N+$ SGR MB $(90-60-60)$ & 1.317ab \\
\hline$T 12=C N+$ DBR MB $(90-60-60)$ & $1.347 \mathrm{a}$ \\
\hline Grand Mean & 0.964 \\
\hline C.V. $(\%)$ & 16.877 \\
\hline
\end{tabular}

Treatment mean within the column with a common letter are not significantly different from each other at $5 \%$ probability level based on Duncan' Multiple Range Test (DMRT).

Legend: $C N=$ corn; $P N=$ peanut; $M B=$ mungbean; $S G R / D B R=$ single/double row 
Treatments with $45 \mathrm{~kg} \mathrm{~N} / \mathrm{ha}$ regardless of the legume intercrop and row intercropping scheme obtained LER values that fell near or equal to one. These results implied that both intercropping and monocropping had no advantage over the other. On the other hand, treatments with no $\mathrm{N}$ were observed below one. This means that monocropping was more advantageous than intercropping.

"There was an increase in LER value as $N$ increased. This result implied that $\mathrm{N}$ played a vital role in promoting better growth and development of the crops. It was also observed that intercropping corn with mungbean at higher level of $\mathrm{N}$ significantly obtained higher LER value compared to the intercropping treatments at low $\mathrm{N}$ level. This implied that intercropping corn with mungbean regardless of the row intercropping scheme performed well when given higher $\mathrm{N}$-level per hectare.

\section{Production Cost and Profitability Analysis}

Gross margin of corn+legume intercropping was directly related to the level of $N$ application (Table 8). Gross margin increased as the level of $\mathrm{N}$ was increased. This result was caused by the effect of $\mathrm{N}$ application to plants. Plants applied with $\mathrm{N}$ grew more vigorously than with no $\mathrm{N}$ and yielded higher as a consequence of better growth performance.

Intercropping corn with peanut obtained higher gross margin than corn intercropped with mungbean in all levels of $\mathrm{N}$ regardless of the intercropping scheme. This result could be attributed by the better yield of peanut with high grain price per kilo than mungbean intercrop. 
Table 8. Cost and profitability of corn+legume combination as influenced by $\mathrm{N}$-levels and row intercropping schemes.

\begin{tabular}{|c|c|c|c|c|c|c|c|c|c|}
\hline \multirow{2}{*}{ Trealnenls } & \multicolumn{3}{|c|}{ Grain Yield (I had } & \multicolumn{3}{|c|}{ Gross lncome (Pha) } & \multirow{2}{*}{$\begin{array}{c}\text { Tolal } \\
\text { Gross } \\
\text { Irrome } \\
\text { (ק) }\end{array}$} & \multirow{2}{*}{$\begin{array}{l}\text { Prods:- } \\
\text { lont } \\
\text { Cost } \\
\text { (P) }\end{array}$} & \multirow{2}{*}{$\begin{array}{c}\text { Gross } \\
\text { l.targin } \\
\text { (P) }\end{array}$} \\
\hline & $\mathrm{CN}$ & PHA & 318 & $\mathrm{CH}$ & Pit & $\mathrm{B} B$ & & & \\
\hline $\begin{array}{l}11=\mathrm{CH}+\mathrm{SGR} P N \\
(0-6060)\end{array}$ & t1 $258 c$ & $0325 \mathrm{C}$ & & 1.806 & 11.410 & & 13216 & 942460 & 379140 \\
\hline $\begin{array}{l}\mathrm{T} 2=\mathrm{CN}+\mathrm{CBR} P \mathrm{PN} \\
(0.60-60)\end{array}$ & $0.302 \mathrm{c}$ & $0.408 b$ & & 2.114 & 14.280 & & 15394 & 11.970 .30 & 4.42300 \\
\hline $\begin{array}{l}\mathrm{T} 3=\mathrm{Cl}+\mathrm{SGR}\} \mathrm{IS} \\
\{0.6060\}\end{array}$ & $0.385 d \theta$ & & $00960 c$ & 2702 & & 2.880 & 5.582 & 804590 & 2.46690 \\
\hline $\begin{array}{l}74=C N+D B R B A \\
(0-60-60)\end{array}$ & 03566 & & $0157 b$ & 2492 & & 4.710 & 7202 & 859870 & -139370 \\
\hline $\begin{array}{l}\mathrm{T5}=\mathrm{CH}+\mathrm{SGRPHH} \\
(45-60-60)\end{array}$ & $0.952 \mathrm{~cd}$ & $0.287 \mathrm{~d}$ & & 6.654 & 10,045 & & 16709 & 9.42791 & 7.28109 \\
\hline $\begin{array}{l}T 6=C H+08 R \text { PII } \\
(45-60-60)\end{array}$ & 09 hacd & 03080.9 & & 6.748 & 10.780 & & 17528 & 1134644 & 6.18759 \\
\hline $\begin{array}{l}17=\text { C. + SGR I.SB } \\
(45-60-60)\end{array}$ & 103070 & & $0123 \mathrm{bc}$ & 7210 & & 3690 & 10.900 & $\begin{array}{c}805221 \\
6\end{array}$ & 2.84779 \\
\hline $\begin{array}{l}18=\mathrm{CH}+08 \mathrm{R} 1.18 \\
(45.6060)\end{array}$ & $1224 k x$ & & 07916 & 8558 & & 2730 & $1129 \mathrm{~B}$ & 858901 & 270899 \\
\hline $\begin{array}{l}19=C N+S G R P N \\
\{90.60-60)\end{array}$ & 1602 ab & 02423 & & 11214 & 8470 & & 19.684 & 1010363 & 950837 \\
\hline $\begin{array}{l}\text { T10: GI+TOBRPIH } \\
(90.60 .60)\end{array}$ & $1.192 t c c$ & $0255 a$ & & 10448 & 6925 & & 19356 & $12 \overline{615} 13$ & 735287 \\
\hline $\begin{array}{l}{[1]=C N+\text { SGR } 1.16} \\
\{90.60 .60)\end{array}$ & 1876 a & & $0 \overline{B A c}$ & 13132 & & 2220 & $1535 ?$ & $32 \div$ & $65240 \bar{T}$ \\
\hline $\begin{array}{l}\text { T12=CN }+ \text { DBR }+.19 \\
(90-60-60)\end{array}$ & 1640 at & & $t+1 f 1 b c$ & $114 \mathrm{~d}$ & & 3350 & 14810 & 92847 & $5.5452 \overline{7}$ \\
\hline $\begin{array}{l}713=\cos 3 \operatorname{ton} 3 \\
(50.60 .60)\end{array}$ & $185\{t a$ & & & 13020 & & & $13 \mathrm{~B} 2 \mathrm{t}_{\mathrm{s}}$ & 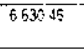 & 638954 \\
\hline $\begin{array}{l}\text { I14: peanut dlone } \\
(90-60-60)\end{array}$ & & 07563 & & & 26450 & & 26460 & $11360 \bar{s} \bar{i}$ & 15.06933 \\
\hline $\begin{array}{l}15=\text { mingtean alone } \\
{[0-60-60)}\end{array}$ & & & 02750 & & & 8.250 & 8250 & $5.9370 \overline{7}$ & 231293 \\
\hline
\end{tabular}

Legend: $\mathrm{CN}=$ corn; $\mathrm{PN}=$ peanut; $\mathrm{MB}=$ mungbean; $\mathrm{SGR} / \mathrm{DBR}=$ single/double row

Single row intercropping scheme of corntpeanut 'and corn+mungbean intercropping combinations obtained higher gross margin than double row intercropping scheme in treatments applied with $\mathrm{N}$ due to the high production cost incurred in double row intercropping scheme with only a little difference in the yield per hectare with the single row intercropping scheme.

Production losses were also observed in treatments of corn+mungbean combination without $N$. This result was caused by the combined effect of no $\mathrm{N}$ application and inclement weather to the crops. 
Crops with no $\mathrm{N}$ were stunted; corn ears were small with few grains and mungbean pods were short with few grains. Heavy rainfall and strong winds also affected the pollination of corn which resulted to the production of fewer grains per ear and damaged several mungbean pods, thus reducing grain yield below the economic threshold. The high gross margin obtained by monocropping of peanut was attributed by the combined yield of the crop at high plant population per unit area with high market price of grains per kilo.

\section{CONCLUSION AND RECOMMENDATION}

Based on the results of the study, the following conclusions were drawn:

1. Application of $90 \mathrm{~kg} \mathrm{~N} / \mathrm{ha}$ to corn using double row intercropping scheme promoted the vegetative growth of the component crops. Corn and mungbean grew taller than corn and mungbean in the other treatments.

2. Intercropping corn with single row mungbean gave high harvest index at high N-levels: $60 \mathrm{~kg} \mathrm{~N} / \mathrm{ha}$ for corn and 30 $\mathrm{kg} \mathrm{N} / \mathrm{ha}$ for mungbean (a total of $90 \mathrm{~kg} \mathrm{~N} / \mathrm{ha}$ ).

3. Application of $90 \mathrm{~kg} \mathrm{~N} . / \mathrm{ha}$ increased the LER of the intercropping system over the monocropping of each crop.

4. Corn+peanut intercropping combination gave higher gross margin per hectare than corn+mungbean combination in all levels of $\mathrm{N}$. 
5. Single row intercropping scheme of either legume intercrop when applied with $\mathrm{N}$ gave higher gross margin than double row intercropping scheme

The use of single row intercropping scheme with peanut as intercrop to corn is recommended to obtain higher gross margin at low production cost per hectare.

\section{LITERATURE CITED}

BAKER, L.F. and NORMAN, D.W. 1975. Cropping Systems in Northern Nigeria. pp 334-361. In: Proceedings on the Production and Cropping Systems Workshop. IRRI, Los Baños, Làguna. Philippines.

CATINGAN, B.D. 1982. Growth, yield and yield components of flint corn as influenced by varying nitrogen levels and row spacing. BSA Thesis. Visayas State College of Agriculture. Baybay, Leyte. 69 pp.

HERRERA, W.A.T., SAMSON, B.T. and HARDWOOD, R.R. 1976. The effect of row arrangement and plant density of corri-rice and corn-peanut intercrops. Phil. Jour. Crop Sci. 1 (3): 125128. 


\section{ABOUT THE AUTHOR}



The author earned the degree of Bachelor of Science in Agriculture major in Agronomy in 1987 at the then Visayas State College of Agriculture (ViSCA) now the Leyte State University (LSU). After graduation, he worked as Research Assistant in the Department of Forestry. He pursued his graduate studies in LSU leading to the degree of Master of Science major in Agronomy. He was hired as Science Research Assistant at the Farm and Resource Management Institute (FARMI). Presently, he teaches at the Tiburcio Tancinco Memorial Institute of Science and Technology (TTMIST).

The co-author is a professor of the Department of Agronomy and Soil Science and is the major adviser of the senior author. 